Bente Helen Skjelbred

Høgskulen på Vestlandet

Jorunn Spord Borgen

Norges Idrettshøgskole / Høgskulen på Vestlandet

DOI: http://dx.doi.org/10.5617/adno.6438

\title{
Ungdomsskolelæreres oppfatninger av tegning sett i lys av den grunnleggende ferdigheten "å skrive" i kunst og håndverk
}

\section{Sammendrag}

Denne artikkelen belyser tegning som del av kunst- og håndverksfaget $i$ den formelle og oppfattede lcreplanen. Artikkelen undersøker hvordan tegning beskrives i lareplan og støttemateriell, og hvordan lcerere på fire ungdomsskoler oppfatter tegning knyttet til lcereplanens beskrivelse av den grunnleggende ferdigheten «å skrive» $i$ kunst- og håndverksfaget.

Resultatene av dokumentanalysen viser at det er uavklarte forhold mellom de verbene som er brukt i lareplanen LK06s omtale av den grunnleggende ferdigheten «å skrive» og kompetansemål i faget. Lcreplanens beskrivelse av «å skrive» innebcerer bevisst og allsidig arbeid med tegning på alle trinn. Intervjuer viser at dette er ukjent for de fire lererne i undersøkelsen. Den grunnleggende ferdigheten «å skrive» blir av larerne forstått og praktisert som loggskriving, beskrivelser av prosess, og dokumentasjon. Lcreplanen vektlegger allsidig arbeid med tegning, men larerne «ser» ikke dette, og kobler det ikke til kompetansemålene. Lcererne mener at allsidig arbeid med tegning er sentralt $i$ faget, men oppfatter ikke at dette er noe de finner grunnlag for i lareplan og støttemateriell. Samlet sett tyder resultatene på at tegning, slik det omtales $i$ lcreplan og støttemateriell, og lcerernes oppfattelse av tegning knyttet til grunnleggende ferdigheter, er uavklart $i$ kunst- og håndverksfaget.

Nøkkelord: tegning, læreplan, kunst og håndverk, grunnleggende ferdigheter, kompetansemål

Teachers' perceptions of drawing seen in light of the basic skill "writing" in arts and crafts

\section{Abstract}

The article examines the concept of "drawing" as a part of the subject "arts and crafts" (in Norwegian: kunst- og håndverk) in the formal curriculum and the 
curriculum as perceived by teachers and in guidance materials. Further, it examines how teachers in four lower secondary schools interpret drawing related to the curriculum's description of the basic skill of writing in the "art and crafts" subject.

The results reveal unclear relationships between verbs used to describe the basic skill of "writing" and the competence objectives in the "arts and crafts" subject in the current curriculum for Norwegian elementary schools (LK06). The curriculum's description of the basic skill of writing implies conscious and versatile work with drawing at all stages. However, this is unknown to the four teachers interviewed in this project. The teachers understand and practice the basic writing skill in the "arts and crafts" subject as student log writing, descriptions of processes and as documentation of tasks. The curriculum emphasizes versatile work with drawing, but the teachers do not "see" and do not link to the competence objectives. The teachers think that versatile work with drawing is central to the subject, but do not perceive this as based in the curriculum and guidance materials. Overall, the results indicate that the concept of drawing, as described in the curriculum and guidance materials, as well as the teachers' perception of drawing related to basic skills, are unclear in "arts and crafts".

Keywords: drawing, curriculum, arts and crafts, basic skills, competence objectives

\section{Innledning/bakgrunn}

Tradisjonelt har tegning vært en sentral del av kunst- og håndverksfaget i den norske grunnskolen. Faghistorisk forskning (Borgen, 1995; Brænne, 2009, 2011; Kjosavik, 2003; Pedersen, 1999) viser til at tegning har en sentral plass i faget og kan ha mange formål. Tenkningen om tegningens plass i kunst- og håndverksfaget er kommunisert i læreplanplanverket Kunnskapsløftet. Det knytter seg imidlertid stor usikkerhet til hva som faktisk skjer i oversettelsene fra læreplan til praksis i faget (Borgen \& Brandt, 2008; Borgen \& Hjardemaal, 2017; Gulliksen, 2012) og hvordan elevene erfarer faget (Dagsland, 2015). Vi vet lite om hvordan tegning i faget har vært gitt plass i undervisnings- og læringsaktivitetene i ungdomskolen under Kunnskapsløftet (LK06). I fagplanen for kunst- og håndverksfaget blir tegning omtalt i kompetansemål og i beskrivelsen av den grunnleggende ferdigheten å skrive. I denne artikkelen undersøker vi nærmere forholdet mellom tegning som del av kompetansemålene og den grunnleggende ferdigheten å skrive i kunst og håndverk i formell læreplan LK06, samt hvordan lærere i ungdomsskolen oppfatter dette. Kunnskap om lærernes oppfattelse av tegningens plass i faget kan bidra til å belyse problemstillinger som er aktuelle i forbindelse med den pågående fagfornyelsen (Kunnskapsdepartementet, 2016). 


\section{Tegning i kompetansemål og den grunnleggende ferdigheten å skrive}

LK06 som kompetansestyrt læreplan innebærer et handlingsrom for skolene og lærerne og samtidig ansvarliggjøring og forventninger om en kunnskapsbasert praksis (Aasen et al., 2012). LK06 sier hva elevene skal kunne mestre på ulike trinn, formulert i kompetansemål, og læreren kan velge innhold og metode i operasjonaliseringen av disse. To elever kan ha ulikt innhold, men oppnå samme kompetanse, og i kunst- og håndverksfaget er dette sentralt. Formålet med faget er blant annet «utvikling av fantasi, kreativitet, motorikk og håndlag fra det enkle til det mer avanserte» (Utdanningsdirektoratet, 2006, s.2). Gjennom individuell tilpasning kan den enkelte elev få mulighet til å oppleve gleden ved å skape noe individuelt og unikt. Dette forutsetter tid til utprøving og fordypning. Kompetansemålene er formulert med verb etterfulgt av innholdsmål og innebærer at elevenes kompetanse utrykkes gjennom praktisk handling. (Andreassen, 2016; Fjørtoft, 2009) Kompetansemålene i kunst- og håndverksfaget er fordelt under fagets fire hovedområder: visuell kommunikasjon, design, kunst og arkitektur. Tegning er omtalt i to av fagets 21 kompetansemål og i tilknytning til to av hovedområdene etter 10. trinn;

Visuell kommunikasjon: Tegne bildemanus, redigere og manipulere enkle digitale opptak

Arkitektur: Vurdere bruk av egne virkemidler og tegne hus og rom ved hjelp av topunktsperspektiv

I tillegg er tegning omtalt i sammenheng med den grunnleggende ferdigheten å skrive. De grunnleggende ferdighetene er redskaper for læring og utvikling, samtidig som de er integrert i alle fags kompetansemål og omtalt i hver fagplan (Dale \& Øzerk, 2009; Øzerk, 2006).

Enkelte fag vil ha større ansvar for å utvikle sider av de grunnleggende ferdighetene enn andre (Dale \& Øzerk, 2009; Øzerk, 2006). På grunnlag av faghistorien er det rimelig å forstå dette slik at kunst- og håndverksfaget har et særlig ansvar for tegning. Selv om tegning kun er omtalt i to kompetansemål for 10. trinn, har tegning likevel fått en sentral plass i faget når tegning er integrert i den grunnleggende ferdigheten å skrive. Faglige særtrekk skal gi rom for at ferdighetene kan bli uttrykt på ulik måte avhengig av hvordan ferdighetene forstås og hvilken funksjon de har som en del av kompetansen. Hvordan de grunnleggende ferdighetene blir forstått av lærerne er dermed avgjørende for elevenes læringsarbeid og oppnådde kompetanse. I LK06 løftes metodefriheten frem og gir lærerne økt handlingsrom. Hvordan lærerne oppfatter tegning relatert til det å skrive og kompetansemål har betydning for hvordan tegning kommer til uttrykk i faget, og dette har vi lite kunnskap om.

LK06 som læreplanreform er preget av pågående oppdateringer (Kunnskapsdepartementet, 2010; Sivesind \& Westbury, 2016) i en form av forhandlede prosesser (Aasen et al., 2012). Følgeevaluering av LK06 i perioden 2009-2012 påpekte at læreplankravet om å arbeide med de grunnleggende 
ferdigheter i fagene ikke reflekteres i undervisningen (Møller, Ottesen \& Hertzberg, 2010). Dette forklares blant annet med at lærere har fått lite støtte i arbeidet med de grunnleggende ferdighetene (Rønning et al., 2008; Svenkerud, Klette \& Hertzberg, 2012). I følge evalueringen kan det virke som om intensjonen med de grunnleggende ferdighetene ikke har blitt forstått (Møller, Prøitz \& Aasen, 2009). I etterkant av følgeevalueringene har det vært flere revisjoner i læreplanen og i Rammeverket for grunnleggende ferdigheter og veiledningen til denne. Hallås, Holthe, Vindenes og Styve (2012) viser til utydelighet i LK06s relasjon mellom grunnleggende ferdigheter og kompetansemål i kunst- og håndverksfaget. Det rapporteres også i en nylig gjennomført studie at den grunnleggende ferdigheten å skrive ikke er tilstrekkelig godt ivaretatt i det 13-årige opplæringsløpet (Horverak \& Hidle, 2017).

Det er blitt hevdet at de grunnleggende ferdighetene i LK06 ikke ivaretar de praktiske estetiske fagenes egenart, og det er etterlyst en bredere forståelse av meningsbærende ressurser samt at bilder og andre visuelle uttrykk kan være del av de grunnleggende ferdighetene (Berge, 2007). Fra fagmiljøet er tegning fremmet som en sjette grunnleggende ferdighet. Det fokuseres ikke nok på hvor samfunnsovergripende tegning er for å kommunisere visuelt, og at barn som fremtidens aktive, engasjerte og produktive voksne kan tegne, kan være nyttig for morgendagens samfunnsborgere (Frisch, 2015). Dette kan være uttrykk for uavklarte forhold angående læreplanen og interne oppfatninger om fagets egenart (Gulliksen \& Johansson, 2008).

I denne artikkelen tar problemstillingen utgangspunkt i denne bakgrunnen, og undersøker: Hvordan fremtrer tegning knyttet til LK06s beskrivelse av den grunnleggende ferdigheten «å skrive» i lcereplanen, og hvordan blir dette oppfattet av lcerere i kunst- og håndverksfaget i ungdomskolen?

Problemstillingen blir belyst gjennom Goodlads (1979) konseptuelle teori. Del a) av problemstillingen blir belyst gjennom en dokumentanalyse av læreplanen, LK06 og nærlesing av støttemateriellets omtale av tegning i kunst- og håndverksfaget. Del b) blir belyst gjennom en kvalitativ intervjuundersøkelse blant kunst- og håndverkslærere i ungdomskolen.

\section{Teori}

Forskningslitteraturen viser til ulike tilnærminger til hvordan læreplanen utvikles og oppfattes (Engelsen, 2012; Gundem, 1990, 2008; Øzerk, 2006). Læreplanbeslutninger blir tatt på mange nivåer (Engelsen, 2003; Gundem, 2008) og fra flere perspektiver (Lindensjö \& Lundgren, 2000). Engelsen (2012) viser til at Goodlads (1979) begrepssystem gir redskaper for å fange opp forholdet mellom intendert, implementert og realisert læreplan og de dynamiske relasjonene mellom læreplaners ulike representasjoner. Goodlad $(1979,1966)$ definerer teorien som et konseptuelt system og viser til at et konsept er bygd opp av flere teorier som 
bidrar til deler av konseptet, og som dermed favner bredere enn en enkelt teori. En svakhet med det konseptuelle systemet er at det vil være mindre presist (Goodlad, 1979) og må operasjonaliseres. Gundem (1990) viser til at Goodlads læreplanteori er en «allmenn læreplanteori» som kan fungere som utgangspunkt for begrepsmessig, teoretisk og empirisk læreplanforskning. Goodlad (1979, 1977) omtaler hvordan læreplanen fremtrer på fem ulike måter:

Ideal, or what some planning group has proposed as an alternative; formal, or what some controlling agency has prescribed; perceived, or what teachers (and others) think it is; operational, or what can be observed, at least in its outward manifestations; and experienced, or what the student relates to (Goodlad, 1977, s. 5).

Studier viser at avstanden kan være stor mellom disse overgangene som gjerne er omtalt som den ideologiske, den formelle, den oppfattede, den operasjonaliserte og den erfarte lcereplanen (Engelsen, 2012; Gundem, 1990, 2008; Øzerk, 2006). I følge Goodlad $(1979,1977,1966)$ er det sjelden ideene som ligger til grunn for den ideologiske lereplan blir formidlet til elevene i sin originale form, fordi den ikke befatter seg med hvordan læreplanen skal settes ut i praksis. Selv om innholdet kan være intakt, vil den anvendte pedagogikken og metodologisk struktur være med å påvirke praksisen. Den formelle lcereplanen relateres her til Læreplan for Kunnskapsløftet (LK06), (Utdanningsdirektoratet, 2006) der læreplaner for fag viser til formålet, tematiske hovedområder, grunnleggende ferdigheter og kompetansemål. I tillegg følger veiledninger og sidedokumenter som er parallelle styringsdokumenter fra nasjonalt og lokalt nivå. Den oppfattede lcereplanen er slik læreplanen oppfattes av ulike aktører, som skoleledelse, lærere, elever og foresatte, og omtales av Goodlad (1979) som «the curricula of the mind». Den formelt vedtatte læreplanen er ikke nødvendigvis den samme som den enkelte person eller gruppe oppfatter å være læreplanen. Det vil si at læreplanens innhold fortolkes ulikt. Det er derfor interessant å utforske hvordan lærere oppfatter at tegning i LK06 er knyttet til grunnleggende ferdigheter og kompetansemål i faget, hva de prioriterer og hvilket innhold de velger. Den operasjonaliserte lcereplanen, som beskriver hva lærere faktisk gjør i undervisningen, kan være forskjellig fra den oppfattede læreplan (Goodlad, 1979). Lærernes faktiske praksis i undervisningssammenheng fungerer dermed som en slags utprøving av nasjonal læreplan (Stenhouse, 1975). Den vedtatte læreplanen er ikke nødvendigvis den samme som den erfarte læereplan, som beskriver hva den enkelte person eller gruppe erfarer. Tidligere forskning viser at det kan være stor forskjell mellom formell læreplan og det praktiske arbeidet (Dagsland, 2013; Engelsen, 2012; Gundem, 1990; Øzerk, 2006), noe som betegnes som et gap mellom det utdanningsmyndighetene ønsker å få til og det lærere og elever faktisk gjør (Engelsen, 2012). Begrepene «en læreplan som ikke eksisterer» og «den skjulte læereplan» brukes gjerne som bidrag til klargjøring av Goodlads læreplannivåer (Andreassen, 2016; Engelsen, 2012). I denne artikkelen refereres det til begrepet «en lcereplan som ikke eksisterer», med bakgrunn i at 
lærerens forståelse av læreplanen ikke behøver å stemme overens med lærerens oppfattelse av fagets egenart, og der lærerens oppfatninger om faget (Gulliksen \& Johansson, 2008) blir førende for undervisningen.

Styrken ved Goodlad (1979) sin konseptuelle teori er at den kan bygge bro mellom praktikere og teoretikere og gi et begrepssystem som legger til rette for felles kommunikasjon og forståelse (Gundem, 1990). Samtidig er det viktig å minne om at de ulike fremtredelsesformene er dynamiske og glir over i hverandre (Goodlad, 1966).

Voogt og Nieveen (2017) hevder med referanse til Goodlad (1979) at det er en tidsforsinkelse (timelag) i enhver læreplanreform. Veien fra intendert til implementert og realisert læreplan preges på ulike måter av den nasjonale og lokale utdanningspolitiske konteksten, læreres kompetanse og oppfatninger, skolekultur, tid og ressurser samt ulikt støttemateriell (guidance materials) Voogt og Nieveen (2017, s. 12). Eksemplene Voogt og Nieveen (2017) viser til er støttemateriell som skal bidra til tverrfaglige koblinger i læreplanreform utviklet av skolemyndighetene i Hong Kong og veiledninger for lærere som etterspør hjelp til operasjonalisering av kompetansemål, utviklet av Utdanningsdirektoratet i Norge.

I denne studien oppfatter vi støttemateriell som tekster som har som formål å styrke sammenhengene mellom formell, oppfattet og operasjonalisert læreplan. Det vil si tekster som forklarer sammenhenger, legger rammebetingelser og gir veiledning som representerer en form for sentrale styringssignaler som også har innholdsmessige konsekvenser for lærerne i deres arbeid med å operasjonalisere læreplanen knyttet til forholdet mellom den grunnleggende ferdigheten å skrive og kompetansemålene. Dette støttemateriellet er: LK06s forenklede Kunnskapsstige basert på Blooms taksonomi (Bloom, 1956), Udirs Rammeverk for grunnleggende ferdigheter samt Udirs veiledning.

I den formelle læreplanen LK06s kompetansemål er verbene valgt med utgangspunkt i at de skal kunne kategoriseres etter et hierarkisk system, også kalt en kunnskapsstige, bygd på Blooms taksonomi. Disse verbene beskriver de grunnleggende ferdighetene og kompetansemålene og gir premisser for hvordan innholdet i LK06 skal tolkes av lærerne. I en kompetansebasert læreplan får verbene i kompetansemålene stor betydning for hvordan tegning realiseres i faget. Selve kompetansebegrepet i LK06 er ifølge Andreassen (2016) uklart. Vi forstår kompetansebegrepet som et komplementært forhold mellom ferdigheter og kunnskaper som vises i relasjon til hverandre.

Rammeverket for de grunnleggende ferdighetene er et styringsdokument som har vært et redskap for læreplangruppene i fagene i LK06 (Utdanningsdirektoratet, 2017). Rammeverket definerer ferdighetene på et overordnet nivå og skisserer hvilke ferdighetsområder disse består av (Utdanningsdirektoratet, 2017). Fellesfagene i den 10-årige grunnskolen ble revidert ut fra dette rammeverket i 2012. I Rammeverket (2012) er skriving definert som å kunne ytre seg forståelig og på en hensiktsmessig måte om ulike 
emner samt å kommunisere med andre. I forbindelse med arbeidet med fagfornyelsen Meld. St. nr. 28 (Kunnskapsdepartementet, 2016) er dette rammeverket nylig blitt revidert (Utdanningsdirektoratet 8.11.2017).

I tillegg er Utdanningsdirektoratets veiledning knyttet til grunnleggende ferdigheter en støtte for lærerne i deres arbeid med å tolke og operasjonalisere læreplanen. LK06 og støttemateriellet er tilgjengelig på Utdanningsdirektoratets nettsider, og publiseres ikke i papirformat. Sammen med lokal skoleeiers læreplan utgjør dette lærernes tolkningsrom. Lærerne analyserer læreplanens innhold for å utforme lokale læreplaner og tilpasser dem til elevenes forutsetninger og andre rammefaktorer (Dale \& Øzerk, 2009; Engelsen, 2012), og lærernes oppfattelse av læreplanen blir slik et bindeledd mellom en formell læreplan på den ene siden og en operasjonalisert og erfart læreplan på den andre siden.

\section{Metodisk tilnærming}

I arbeidet med å søke svar på problemstillingens to deler ligger Goodlad (1979) sin konseptuelle teori om læreplanens ulike fremtredelsesformer til grunn. Teorien benyttes for å belyse hvordan forholdet mellom tegning, som del av kompetansemålene, og den grunnleggende ferdigheten å skrive i kunst- og håndverksfaget fremtrer i en formell læreplan og dens støttemateriell og lærernes oppfattelse av tegning knyttet til disse identifikasjonene. I en empirisk, kvalitativ intervjuundersøkelse ønsker vi å synliggjøre på hvilke måter tegning har en plass og betydning i læreres didaktiske praksis. Gjennom å fokusere på lærernes beskrivelser av egen undervisningspraksis, belyses sammenhenger mellom formell og oppfattet læreplan. Vi skal her først se nærmere på to av 21 kompetansemål for 10. trinn der tegning er gitt plass, samt den grunnleggende ferdigheten å skrive.

Basert på Goodlad (1979) bygger artikkelen på to typer datagrunnlag og to typer analyser, foretatt i to trinn: a) formell læreplan og b) oppfattet læreplan. Resultatene presenteres og diskuteres hver for seg, og deretter diskuteres funnene i a og b i relasjon til hverandre.

\section{Del a) formell læreplan}

Dokumentanalyse

En innholdsanalyse (Fauskanger \& Mosvold, 2014; Hsieh \& Shannon, 2005) er gjennomført for å belyse problemstillingens første del for å studere meninger i tekster, både kvantitativt og kvalitativt. Dette innebærer her en summativ innholdsanalyse av forekomsten av bestemte ord i en bestemt kontekst, i denne sammenhengen verb og begreper i læreplanen og støttemateriell. For å få tak i hvilke føringer som ligger til grunn for lærerens tolkning, omfatter analysen også en konvensjonell innholdsanalyse der kategorier for koding av data blir utviklet 
induktivt (Fauskanger \& Mosvold, 2014) i tilknytning til hvordan tegning kommer til uttrykk i følgende tekster:

1) Læreplanen LK06s omtale av den grunnleggende ferdigheten å skrive i kunst- og håndverksfaget,

2) Verb i fagets kompetansemål, og LK06s tredelte utgave av Kunnskapsstigen,

3) Udirs Rammeverks beskrivelse av ferdighetsområder og nivåbeskrivelse av å skrive, og

4) Udirs veiledning vedrørende det å skrive i praktisk estetiske fag.

\section{Del b) oppfattet læreplan}

\section{Intervjuer}

For å belyse problemstillingens andre del benyttes en kvalitativ, konvensjonell innholdsanalyse (Fauskanger \& Mosvold, 2014; Hsieh \& Shannon, 2005) basert på intervjudata samlet inn i forbindelse med en større casestudie om tegning i kunst- og håndverksfaget høsten 2017. Casestudien har et utforskende design (Yin, 2003; Yin \& Nilsson, 2007). Intervjuguiden ble utviklet med sikte på å undersøke lærernes oppfattelse av læreplanen og realiseringen av faget i skolen og inneholdt spørsmål knyttet til grunnleggende ferdigheter, kompetansemål, hovedområder, planlegging og gjennomføring relatert til tegning i faget. Det ble gjennomført en pilotundersøkelse med lærere på 10. trinn i mai 2017, og etter piloten ble det foretatt noen små justeringer i intervjuguiden. Informantene er identifisert som lærer A, B, C og D.

\section{Utvalgskriterier}

Casestudien har et strategisk utvalg av fire erfarne lærere, med 30 studiepoeng eller mer, som underviser på 8.-10. trinn i faget kunst og håndverk ved fire skoler på Vestlandet. Skolene A, B, C og D har alle ca. 350-400 elever og ca. 50 ansatte.

\section{Etikk}

Studien er godkjent av Norsk Samfunnsvitenskapelig Datatjeneste (NSD) og har fulgt retningslinjene som gjelder frivillig deltagelse, informert samtykke fra lærer og skoleledelse, avidentifisering og anonymitet. Lærerne var på forhånd informert skriftlig og muntlig om at prosjektet hadde fokus på tegning i kunst- og håndverksfaget. I henhold til kravene som stilles i Forskningsetiske retningslinjer for samfunnsvitenskap, humaniora, juss og teologi (Kalleberg et al., 2006) inngår en avtale med alle deltagerne i prosjektet om hvordan dataene skal brukes.

\section{Analyse av data}

Studiens data ble samlet inn gjennom kvalitative intervjuer med lærere gjennomført som individuelle, halvstrukturerte intervjuer (Kvale \& Brinkmann, 2015) registrert med digital lydopptaker og transkribert. I arbeidet med 
behandling av datamaterialet ble det benyttet konvensjonell innholdsanalyse (Fauskanger \& Mosvold, 2014; Hsieh \& Shannon, 2005) som forskningsmetode for den subjektive tolkningen av innholdet i teksten.

Casestudien har en kvalitativ design, og generalisering er ikke mulig (Kvale \& Brinkmann, 2015). I presentasjonen av resultatene er sentrale poeng fra analysen illustrert ved å hente ut enkelte sitater fra intervjuene. Av hensyn til anonymitet er alle sitatene på bokmål.

\section{Resultat-/diskusjonsdel}

\section{Analyse a) formell læreplan;}

I LK06 introduseres grunnleggende ferdigheter gjennom et kort avsnitt som knytter ferdighetene til kompetansemålene i de ulike fagene på det enkelte fags premisser. De fem ferdighetene knyttet til kunst- og håndverksfaget vektlegger estetiske virkemidler, visuell kommunikasjon og visuell kompetanse og ferdighet. I beskrivelse av den grunnleggende ferdigheten å skrive er det visuelle fremtredende.

\section{1) Tegning i LK06s toleddete beskrivelse av å skrive}

LK06s omtale av den grunnleggende ferdigheten å skrive har to ledd (se tabell 1).

Tabell 1: Formell læreplans omtale av den grunnleggende ferdigheten å skrive i kunst og håndverk

\begin{tabular}{|l|l|}
\hline 1.ledd & $\begin{array}{l}\text { «A kunne uttrykke seg skriftlig i kunst og håndverk innebærer blant annet å } \\
\text { uttrykke seg visuelt ved hjelp av tegn og symboler. Utvikling av skriftlig og } \\
\text { visuell kompetanse skjer ved å omsette fakta, ideer og holdninger til tegn. }\end{array}$ \\
\hline 2.ledd & $\begin{array}{l}\text { For å opprettholde den visuelle ferdigheten parallelt med utviklingen av } \\
\text { skriveferdigheten er bevisst og allsidig arbeid med tegning like viktig på alle } \\
\text { trinn» }\end{array}$ \\
\hline
\end{tabular}

Hvordan verbene i kompetansemålene gjenspeiler den grunnleggende ferdigheten, og hvordan den kan uttrykkes, er avgjørende for hvordan tegning blir oppfattet og realisert i faget. De fem handlingsverbene utrykke, utvikle og omsette, i første ledd, opprettholde og arbeid med, i andre ledd, beskriver handlinger og er brukt i omtalen for kunst- og håndverksfaget. Verbet utrykke er delvis fagspesifikt, men forekommer også i andre fag. Andre verb i omtalen av ferdigheten er ikke fagspesifikke og sier ikke noe om fagets egenart. Første ledd henviser i stor grad til en forståelse av å skrive som bruk av tegn og symboler, og kan slik sett forstås som å omfatte mer enn kun bokstaver og tekst. Andre setning i første ledd sidestiller utvikling av skriftlig og visuell kompetanse idet fakta, ideer og holdninger omsettes til tegn. Innledningen til andre ledd viser til at den visuelle ferdigheten skal opprettholdes parallelt med utvikling av skriveferdigheten. Dette skal skje gjennom bevisst og allsidig arbeid med tegning. Andre ledd i 
beskrivelsen utvider dermed å skrive til å omfatte tegning som bevisst og allsidig arbeid på alle trinn. I formuleringen «allsidig arbeid med tegning» er verbet tegne substantivert. Adjektivene bevisst og allsidig beskriver de substantiverte verbene uten å definere eller vise til metode eller innhold. For å kunne identifisere verbene må man se på sammenhengen mellom allsidig arbeid med tegning og verbene $\mathrm{i}$ kompetansemålene. Denne åpne beskrivelsen av å tegne sier ikke noe om hvem som gjør eller skal gjøre noe og hvordan og på hvilket nivå det skal gjøres. Dette gir læreren et stort tolkningsrom.

\section{2) Taksonomi knyttet til tegning i LK06}

LK06s forenklede taksonomi Kunnskapsstigen, er en tredelt utgave basert på Blooms (1956) taksonomi (Isnes, 2007), og utgjør en del av støttemateriellet som ligger til grunn for det som er ment å være verbstrukturen i (og operasjonaliseringen av) kompetansemålene. Blooms (1956) taksonomi er en målkategorisering av undervisning og vurderingskriterier fra det enkle til det komplekse i seks trinn: faktakunnskap, forståelse, anvendelse, analyse, syntese og vurdering. Verbene i LK06s kompetansemål beskriver og stiller ulike krav i forhold til om elevene skal reprodusere, forstå og anvende, analysere og gjøre vurderinger etter denne Kunnskapsstigen (se tabell 2).

Tabell 2: Kunnskapsstigen - LK06s forenklede utgave taksonomi

\begin{tabular}{|l|l|}
\hline Kompetansenivå & Kompetansekrav \\
\hline Lavt nivå & Reproduksjon \\
\hline Middels nivå & Forståelse og anvendelse \\
\hline Høyt nivå & Analyse og vurdering \\
\hline
\end{tabular}

I kunst- og håndverksfagets kompetansemål er imidlertid få verb taksonomert etter denne kunnskapsstigen. I vår analyse finner vi 19 ulike handlingsverb i beskrivelsen av 21 kompetansemål i faget for 8.-10. trinn. Verbene benyttes etter følgende fordeling (i parentes): vurdere (7 ganger), bruke (4), samtale (3), beskrive (2), stilisere (2), skape (2) og tegne (2 ganger). De resterende 12 verbene er kun brukt en gang hver. Analysen av verbene viser at ingen av de fagspesifikke verbene: tegne, stilisere, designe, skape, lage, skissere og bygge er taksonomert (se tabell 3). 
Tabell 3: Tabellen viser i kolonne a) taksonomerte verb i Kunnskapsstigen. De kursiverte verbene inngår i kunst- og håndverksfagets kompetansemål. Kolonne b) viser de ikketaksonomerte verb i fagets kompetansemål hvorav gruppe c) er fagspesifikke og gruppe d) er generelle verb.

\begin{tabular}{|l|l|l|l|}
\hline $\begin{array}{l}\text { Kompetanse } \\
\text { nivå }\end{array}$ & $\begin{array}{l}\text { Kompetanse } \\
\text { krav }\end{array}$ & $\begin{array}{l}\text { a) Taksonomerte verb i } \\
\text { kunnskapsstigen }\end{array}$ & $\begin{array}{l}\text { b) Ikke- } \\
\text { taksonomerte } \\
\text { verb i kunst og } \\
\text { håndverk }\end{array}$ \\
\hline $\begin{array}{l}\text { Lavt } \\
\text { nivå }\end{array}$ & Reproduksjon & Beskrive, definere, gjengi, presentere & $\begin{array}{l}\text { c) Tegne, stilisere, } \\
\text { designe, skape, } \\
\text { lage, skissere, } \\
\text { bygge } \\
\text { d) teste, redigere, } \\
\text { manipulere, } \\
\text { dokumentere, } \\
\text { samtale, gjøre, } \\
\text { diskutere, vurdere }\end{array}$ \\
\hline
\end{tabular}

Verbene som ikke er taksonomert kan tolkes forskjellig i forhold til kompetansenivå. De fagspesifikke verbene som f. eks. «å tegne» kan rangeres som både lav, middels og høy taksonomi, fordi verbet er knyttet til flere elementer som meningsinnhold, substantiv, flere fagspesifikke ord og grunnleggende ferdigheter. Som vi har vist her blir tegning fremhevet som sentralt under den grunnleggende ferdigheten å skrive, samtidig nevnes tegning kun i to av 21 kompetansemål etter 10. årstrinn. I målet under hovedområdet visuell kommunikasjon, «tegne bildemanus, redigere og manipulere enkle digitale opptak og vurdere bruk av egne virkemidler», er tegning bundet opp til bildemanus. I målet under hovedområdet arkitektur, «tegne hus og rom ved hjelp av topunktsperspektiv», er tegning bundet opp til en teknisk ferdighet. Læreplanen gir få signaler om taksonomisk nivå i disse kompetansemålene, og dette gir læreren et stort tolkningsrom.

Lærernes tolkning av verbene som beskriver kompetansemålene i lys av den grunnleggende ferdigheten er avgjørende for hvilken funksjon tegning får som en del av elevenes læringsarbeid og oppnådde kompetanse. Fordi det benyttes ulike verb i omtalen av den grunnleggende ferdigheten og kompetansemålene, kan det være utfordrende å lese disse i relasjon til hverandre. I tillegg er det lite samsvar mellom de substantiverte verbene brukt $\mathrm{i}$ omtalen av ferdigheten og verb i kompetansemål. For at tegning skal kunne bli en allsidig aktivitet, må de ulike handlingsverbene (tabell 3) tolkes av læreren på en slik måte at de kan inneholde 2. ledd av å skrive (tabell 1). Forholdet mellom den grunnleggende ferdigheten og kompetansemålene virker på denne bakgrunn å være uklart i kunst- og håndverksfaget i LK06, der tegning synes å komme noe tilfeldig til uttrykk i fagets kompetansemål, og manglende taksonomering kan være utfordrende for lærere i operasjonaliseringen av kompetansemål. 


\title{
3) Rammeverkets generelle nivådeling av ferdighetsområder og tegning
}

Rammeverket for grunnleggende ferdigheter (Utdanningsdirektoratet, 2017) har veiledende funksjon for læreplangruppene og er støttemateriell for lærerne. $\AA$ skrive består ifølge Rammeverket av ferdighetsområdene å planlegge og bearbeide, utforme, kommunisere, reflektere og vurdere. I beskrivelsene av grunnleggende ferdigheter, som Rammeverket viser til, utdypes det hvordan dette er knyttet til det å kunne skrive:

\begin{abstract}
Planlegge og bearbeide innebærer å kunne ta i bruk ulike strategier og kilder som forberedelse til skriving, og å være i stand til å revidere tekster på bakgrunn av egen vurdering og andres tilbakemeldinger. $\AA$ utforme innebærer å kunne beherske og ta i bruk rettskriving, grammatikk, setningsoppbygging og tekstbinding på papir og skjerm sammen med andre uttrykksmidler som bilder, figurer og symboler på en hensiktsmessig måte. Kommunisere innebærer å kunne uttrykke meninger, drøfte problemstillinger, dele kunnskap og erfaringer gjennom å tilpasse egne tekster til mottaker, innhold og formål. Reflektere og vurdere innebærer å bruke skriving som redskap for å kunne følge med på og å utvikle bevissthet om egen læring. (Utdanningsdirektoratet, 2017, s. 14 - 15). (Vår utheving).
\end{abstract}

Rammebeskrivelsen er inndelt i fire ferdighetsområder, fordelt på fem nivå i matrise, der hver celle beskriver hva som er typisk for elevenes utvikling (Utdanningsdirektoratet, 2017). I de totalt 20 cellene er tegning nevnt kun ett sted, under utforme, på laveste nivå: «Kombinerer ulike uttrykksmidler som tegninger, bilder, symboler og verbalspråk». Dette skaper uklarhet, da tegning her kan forståes som et ferdig element, en tegning, vurdert i sammenheng med et helhetlig utrykk med bilder, tekst og symboler. Matrisebeskrivelsen kan også tolkes som at det er rom for å tegne. LK06s beskrivelse av den grunnleggende ferdigheten $a$ skrive, 2. ledd som «allsidig arbeid med tegning» omtales ikke i Rammeverket. Tegning er heller ikke nevnt under ferdighetsområdet kommunikasjon. Visuell kommunikasjon er ett av kunst- og håndverksfagets fire hovedområder, der tegning forstås som viktig for å kommunisere visuelt (Frisch, 2015). LK06 har dermed en mer variasjonsrik beskrivelse av å skrive i kunst- og håndverksfaget enn det vi finner i Rammeverket (Utdanningsdirektoratet, 2017).

\section{4) Udirs veiledning er mangelfull $i$ henhold til 2. ledd av å skrive}

På Udirs nettsider har vi funnet to tekster under fanen Veiledning som knyttes til det å skrive som en grunnleggende ferdighet i kunst- og håndverksfaget. I teksten «Er skriving viktig i de praktisk og estetiske fagene?»" stilles spørsmålet: «Skal elevene bruke skriving i disse fagene, og hvorfor skal de i så fall det?» Veiledningen viser til det å skrive som dokumentasjon av elevens arbeidsprosesser, rapport, logg, vurdering og multimediepresentasjon. Den andre

\footnotetext{
${ }^{1}$ https://www.udir.no/laring-og-trivsel/lareplanverket/grunnleggende-ferdigheter/skriving/eksempler-pa-godpraksis-i-skriving/skriving-prakt-est-fag/er-skriving-viktig/
} 
teksten, «Skriving som grunnleggende ferdighet i de praktisk estetiske fagene» ${ }^{2}$, eksemplifiserer det å skrive som dokumentasjon av en arbeidsprosess og «skrive» med nål (geriljabroderi). Begge disse tekstene viser implisitt til 1. ledd i den grunnleggende ferdigheten å skrive i kunst- og håndverksfaget og omtaler ikke allsidig arbeid med tegning i 2. ledd. Begge tekstene er lastet ned 26.10.17.

\section{Drøfting: LK06 og støttemateriell - komplekst og uklart}

Analysen viser at det er et komplekst og uklart forhold mellom verb brukt i omtalen av den grunnleggende ferdigheten å skrive og verb som omtales i kunstog håndverksfagets kompetansemål. I læreplanen for faget fremkommer ikke taksonomi i de fagspesifikke verbene i kompetansemålene. Det er på denne bakgrunn uklart hvordan verb som tegne, designe, skissere, stilisere og skape kan plasseres innenfor Kunnskapsstigen, og det kan se ut som om verbene ikke er taksonomert i kompetansemålene. Dette kan være tilfeldig eller tilsiktet fra læreplangruppens side. Hvis vi tenker at allsidig arbeid med tegning skal foregå i faget på alle nivå i Kunnskapsstigen, kan det være utfordrende at det mangler taksonomering. Når fagspesifikke verb ikke er taksonomert, gis det ingen signaler fra læreplanen som styringsdokument knyttet til ambisjonene om at tegning er en forutsetning for visuell kompetanse. Det innebærer at lærerne ikke får hjelp i støttemateriellet til å få tegning inn på alle nivå i Kunnskapsstigen når de operasjonaliserer læreplanen. Manglende taksonomering av verbene i kompetansemålene og manglende henvisninger relatert til begge ledd i den grunnleggende ferdigheten å skrive, slik som denne analysen viser at den formelle læreplanen kommuniserer, skaper uklarhet.

Samlet sett gir analysen av formell læreplan et inntrykk av at sammenhengene mellom den formelle læreplanens ulike elementer i faget, her LK06s kompetansemål og den grunnleggende ferdigheten å skrive sett $\mathrm{i}$ lys av Kunnskapsstigen, Rammeverket og veiledningsmateriell, er uklare. Det er derfor interessant å undersøke lærernes oppfattelse av den grunnleggende ferdigheten og kompetansemål i faget.

\section{Analyse b) oppfattet læreplan}

For å belyse problemstillingens andre del om hvordan tegning knyttet til LK06s beskrivelse av den grunnleggende ferdigheten å skrive blir oppfattet av lærere i kunst- og håndverksfaget i ungdomskolen, har vi basert oss på en kvalitativ konvensjonell innholdsanalyse (Fauskanger \& Mosvold, 2014; Hsieh \& Shannon, 2005) av intervjudata samlet inn i forbindelse med en større casestudie om tegning i kunst- og håndverksfaget høsten 2017.

\footnotetext{
${ }^{2}$ https://www.udir.no/laring-og-trivsel/lareplanverket/grunnleggende-ferdigheter/skriving/eksempler-pa-godpraksis-i-skriving/skriving-prakt-est-fag/skriving-grlf/
} 


\section{Lærernes oppfattelse av å skrive i kunst og håndverk}

I intervjuene ble lærerne spurt om hvordan de oppfatter den grunnleggende ferdigheten å skrive i kunst og håndverk. Lærerne oppfattet dette som konkrete skriveaktiviteter, eksemplifisert som loggføre, dokumentere, presentere, formulere, skrive ned tanker, fagbegreper, vurdering, begrunnelser, beskrivelser, fortelle, sette ord på ting og ideer. Som lærer D uttrykte det: «skriving det dekker vi. Ikke akkurat i tegneoppgavene, men i andre oppgaver». Hun viste til anvendelse av den grunnleggende ferdigheten «elevene forteller hva de har gjort, lcert, og hvordan de vurderer eget arbeid, setter ord på ideer og beskriver bilder». Lærer $\mathrm{C}$ valgte vekk det hun beskrev som å skrive i faget; «skriving, det gjør de så mye i andre fag, i mine timer så skal elevene få gjøre litt andre ting».

Ut fra datagrunnlaget i denne studien fremgår det at lærerne knytter den grunnleggende ferdigheten til ulike former for skriving av tekster. Relatert til analyse a samsvarer lærernes oppfatning med første ledd av å skrive (tabell 1), som å skrive i tilknytning til oppgaver, og ikke som en utvidet forståelse av å skrive på fagets premisser, som beskrevet i 2. ledd av å skrive. Rommet for tolkning av skriving i kunst- og håndverksfaget ser på denne bakgrunn ikke ut til å bli utnyttet av lærerne. En kan tenke seg at hvis 2. ledd i definisjonen blir «oversett» av lærerne, kan det innebære at LK06s vektlegging av å opprettholde den visuelle ferdigheten parallelt med skriveferdigheten ikke blir realisert. I lys av Goodlad (1979) kan det forklares med at der formell læreplan inviterer til variasjon i tegning, er den oppfattede læreplanen variasjonsfattig. Samtidig antyder materialet at lærerne har tatt stilling til at den grunnleggende ferdigheten å skrive er «noe annet» enn tegning i kunst- og håndverksfaget.

Når lærerne ble spurt hvordan de oppfattet «allsidig arbeid med tegning», uten henvisning til LK06, fremkom en variasjonsrik beskrivelse som innbefattet ulike tegneaktiviteter, metoder og formål, som for eksempel lærer A viste til: «arbeidstegning, kroki og kinetisk tegning, friere tegning og skisser og at elevene tegner det de tenker». Lærer $C$ vektla at elevene ble utfordret til å tegne ideer og henviste til variasjon i ulike tegneredskap, format, og tempo. Tegning knyttet til visuell kommunikasjon ble også fremhevet som vesentlig. Når de fire lærerne fremhever allsidig arbeid med tegning som viktig i faget, kan det tyde på at lærerne mener de har en annen forståelse av hvordan tegning i faget bør være, enn det de finner grunnlag for i LK06 og støttemateriell. Som lærer B uttrykte det: «å jobbe med tegning på mange forskjellige måter og nivå er vi ikke flinke på». Lærer C presiserte at hun praktiserte allsidig arbeid med tegning på tross av LK06. Kontrasten mellom lærernes oppfatning av å skrive i faget og deres forståelse av allsidig arbeid med tegning (tabell 4), antyder at det her er en svak kobling i faget mellom formell læreplan og oppfattet læreplan. 
Tabell 4: Ideologisk vs. operasjonalisert læreplan

\begin{tabular}{|l|l|lr|}
\hline Lærer & Lærers forståelse av allsidig arbeid med tegning & $\begin{array}{l}\text { Lærers forståelse av å } \\
\text { skrive som grunnleggende } \\
\text { ferdighet i kunst og } \\
\text { håndverk }\end{array}$ \\
\hline A & $\begin{array}{l}\text { Øve opp tegneferdigheter, kroki-, kinetisk-, } \\
\text { blindetegning, tegne mennesker, perspektiv og } \\
\text { arbeidstegning }\end{array}$ & $\begin{array}{l}\text { Loggføre, dokumentere, } \\
\text { presentere, formulere, svare }\end{array}$ \\
\hline B & $\begin{array}{l}\text { Tegne på forskjellige måter og nivåer. } \\
\text { Fantasitegning, illustrasjoner og drodling }\end{array}$ & $\begin{array}{l}\text { Logg, presentasjon, skrive } \\
\text { tanker }\end{array}$ \\
\hline C & $\begin{array}{l}\text { Ulike tegneøvelser som innebærer å tegne følelser, } \\
\text { kommunisere visuelt, arkitektur, konsentrasjons og } \\
\text { arbeidstegning }\end{array}$ & $\begin{array}{l}\text { Logg, fagbegreper, } \\
\text { egenvurdering }\end{array}$ \\
\hline D & $\begin{array}{l}\text { Tegne noe som kan brukes, skisser, tanker, ideer, } \\
\text { visualisere, lære å tegne, skyggelegge, få frem } \\
\text { ansikt, teknisk forklarende og visualiserende } \\
\text { arbeidstegninger }\end{array}$ & $\begin{array}{l}\text { Logg, } \\
\text { begrunnelser, beskrivelser, } \\
\text { fortelle, sette ord på ting, } \\
\text { ideer }\end{array}$ \\
\hline
\end{tabular}

Når lærerne ble spurt om hva de anså som grunnleggende i faget, ga samtlige uttrykk for tegning som sentralt i ungdomskolen. Lærer C sier for eksempel at «tegning er en ganske vesentlig ting en må kunne innenfor de fire hovedområdene». I lys av Goodlad (1979) kan dette forklares med at lærernes idelogier samstemmer med ideologier i formell læreplan, men fordi lærerne ikke oppfatter at LK06 ivaretar deres faglige forståelse, blir tegningens plass i faget avhengig av hvordan lærer velger å forholde seg til det hun oppfatter at den formelle læreplan gir handlingsrom for. Lærer C underviser dermed etter «en lcreplan som ikke eksisterer» (Engelsen, 2012), med begrunnelse i et tema hun mener er viktig, men oppfatter som utelatt i formell læreplan. Således kan «en lcreplan som ikke eksisterer» eller «den ideologiske lcereplan» inngå i den operasjonaliserte læreplanen, selv om den ikke inngår i den oppfattede læreplanen.

Tegning i kompetansemålene blir i liten grad sett i relasjon til den grunnleggende ferdigheten å skrive av lærerne. Lærerne ga uttrykk for at tegning er lite synlig og variert i kompetansemålene. Lærer B sier for eksempel at «Det er ikke mange plasser tegning er uttalt, kun at elevene skal ha om ett og topunkts perspektiv». Lærer A uttrykte at «det er veldig lite kompetansemål igjen som åpner for en såkalt fri oppgave». De intervjuede lærerne oppfattet ikke at de hadde den friheten LK06 gir dem med tanke på valgmuligheter knyttet til tegning. Lærerne etterlyser en mer åpen forståelse av tegning enn de mener de finner i kompetansemålene, som de oppfatter som å ha en lukket og entydig forståelse med spesifikke ferdigheter som det å tegne perspektiv på bestemte måter. Lærerne forstår slik sett tegning konkret opp mot verbene i de kompetansemålene som omtaler tegning (Hallås et al., 2012). De ser ikke mulighetene for at fagets egenart kan ivaretas gjennom «allsidig arbeid med tegning» uttrykt gjennom 2.ledd i omtalen av å skrive som grunnleggende ferdighet. 


\section{Støttemateriellets betydning for lærernes oppfattelse av læreplanen}

Læreren har et stort tolkningsrom da elevenes reproduksjon (lav taksonomi), anvendelse (middels taksonomi), analyse og vurdering (høy taksonomi) knyttet til grunnleggende ferdigheter og kompetansemål ikke fremgår i LK06. Det kan se ut til at det er problematisk å operasjonalisere måloppnåelseskriterier for å vurdere tegning. Som lærer D beskriver det: «jeg forklarer hva elevene skal oppnå gjennom kjennetegn på måloppnåelse, men ser at jeg ikke gjør det tydelig». Lærer C: «Det er kjempevanskelig med vurdering. Jeg har ingen gode svar på det. Mindre og mindre etter hvert». Den manglende taksonomien i LK06 når det gjelder tegning ser ut til å gjøre det vanskelig for lærerne å tolke den grunnleggende ferdigheten opp mot kompetansemål der de fagspesifikke verbene ikke er taksonomert.

Lærerne refererte ikke til, og ble ikke spesifikt spurt om de kjente Rammeverket for grunnleggende ferdigheter. Relatert til analyse a, kan det tolkes som at rammeverkets matrisebeskrivelse opprettholder en forståelse av de grunnleggende ferdighetene som allerede var etablert.

Lærerne i denne studien ønsket ikke at skriving skulle ta stor plass i kunst- og håndverksfaget. De viste til skriving som identisk med det de gjør i andre fag de underviser i (norsk, KRLE, kroppsøving, samfunnsfag) og beskrev dette som logg, refleksjon og dokumentasjon, osv. Til tross for tydelige forskjeller mellom fagene, er det et fellestrekk at skriftlige elevarbeider danner et vesentlig grunnlag for standpunktkaraktersetting (Prøitz \& Borgen, 2010). Lærernes variasjonsfattige forståelse av skriving i faget kan være av nyttehensyn til slike formål og bidra til at lærerne «ser» 1 . ledd av den grunnleggende ferdigheten $a$ skrive, men mister 2 . ledd av syne. Lærernes oppfattelse samsvarer med Udirs to veiledningstekster som viser til 1.ledd i LK06s definisjon.

\section{Oppfattet læreplan knyttet til 1. ledd av den grunnleggende ferdigheten å skrive}

Analysen viser at lærernes forståelse av allsidig arbeid med tegning fremstår variert, men de oppfatter ikke at dette er noe de finner grunnlag for i LK06s omtale av å skrive, og de ser det ikke i sammenheng med kompetansemålene. Lærerne ser ut til å bruke egne assosiasjoner og «common sense» når de vurderer hva det å skrive omfatter. Likevel ble allsidig arbeid med tegning oppfattet som grunnleggende i kunst- og håndverksfaget, og paradoksalt nok savnet, av samtlige lærere.

Læreplankravet om å arbeide med grunnleggende ferdigheter i fagene ser ikke ut til å ha ført til systematisk arbeid med de grunnleggende ferdighetene i faget på de aktuelle skolene (Hallås et al., 2012). Dette kan tyde på at faglige styringssignaler fremdeles er for svake (Møller et al., 2010). Hva lærerne leser, oppfatter og bruker av støttemateriell i sin profesjonelle virksomhet er avhengig av tilgjengelighet og tydelighet i budskap. Som påpekt i underveisevalueringen av LK06 (Engelsen, 2008) har det ikke vært gitt tilfredsstillende veiledning til 
lærerne i hvordan kompetansemålene kan operasjonaliseres. Vi ser dette i at den veiledningen som er tilgjengelig på Udirs nettsider kommuniserer en forståelse jamfør 1. ledd i LK06s omtale av det å skrive i kunst- og håndverksfaget, og at dette samsvarer med lærernes oppfattede læreplan. Debattinnspill om at de grunnleggende ferdighetene ikke bidrar til å ivareta fagets egenart (Berge, 2007; Frisch, 2015) kan ha bidratt til en slik forståelse. Materialet kan tyde på at det stadig er slik at intensjonen med de grunnleggende ferdighetene ikke blir forstått og dermed ikke fremstår som særlig meningsfylt å holde på med (Møller et al., 2009).

\section{Konklusjon}

Innledningsvis viste vi til at det kan være stor avstand mellom en formell læreplan og hvordan den blir oppfattet (Engelsen, 2012; Gundem, 1990, 2008). Denne undersøkelsen finner at handlingsrommet som LK06 åpner opp for med tanke på tegning, ikke synes å bli oppfattet av lærerne. Den svake koblingen mellom sentrale elementer i læreplanen kan gjenfinnes i flere av de praktisk estetiske fagene (Hallås et al., 2012). Basert på Goodlad (1979) finner vi to forhold som virker avgjørende for hvordan tegning knyttet til LK06s beskrivelse av å skrive fremtrer i læreplanen og hvordan dette blir tolket av lærere i kunst- og håndverksfaget i ungdomskolen.

LK06 definerer ikke hva den grunnleggende ferdigheten å skrive i 2.ledds vektlegging av allsidig arbeid med tegning kan innebære av aktiviteter, metoder eller arbeidsformer, og er ellers svakt beskrevet i læreplanen i faget. Verb i kompetansemål gjenspeiler heller ikke den åpne måten å snakke om tegning på som er beskrevet i den grunnleggende ferdigheten å skrive i faget. Taksonomien uttrykkes ikke tydelig gjennom verbene, og det er uklart om dette er tilsiktet i faget. I rammeverkets omtale av den grunnleggende ferdigheten å skrive finner vi en ufullstendig beskrivelse av tegning, og Udirs veiledningstekster omtaler skriveaktiviteter, jamfør 1. ledd i LK06. Intervjuene med lærerne viser at de har forholdt seg til 1 . ledd, men ikke 2 . ledd av det å skrive som grunnleggende ferdighet. Lærerne etterlyste en åpen forståelse av tegning, men i kompetansemålene fant de en mer lukket og entydig forståelse med spesifikke ferdigheter. Dette kan tyde på at kompetansemålene forstås separat og ikke kobles til de grunnleggende ferdighetene, selv om dette er koblet sammen i LK06.

Det kan også virke som lærerne har en læreplanideologi om at fagets egenart ikke blir tilstrekkelig ivaretatt i dagens læreplan, idet de har en annen forståelse av hvordan tegning i faget bør være, enn det de finner i grunnlag for i LK06 og støttemateriell.

I lys av Goodlad (1979) antyder våre funn at sidestilling av skriftlig og visuell kompetanse krever tydeligere og mer omfattende omtale, taksonomering av fagspesifikke verb i kompetansemålene og en tydeligere fremskriving av fagets 
egenart enn det vi finner i dagens læreplan og støttemateriell. Det er alltid tidsforsinkelser i implementering av en læreplanreform (Voogt \& Nieveen, 2017), og uklare signaler i formell læreplan og støttemateriell kan se ut til å ha preget kunst- og håndverksfaget i LK06. Nå står vi overfor en ny reform, L2020, og det gir muligheter for en tydeliggjøring av slike forhold.

Som tidligere nevnt kan det være forskjell mellom hva lærerne oppfatter at læreplanen gir av føringer og deres faktiske praksis i undervisningssammenheng (Goodlad, 1979). For videre forskning vil det derfor være viktig å undersøke operasjonalisert læreplan for å få mer utfyllende kunnskap om hvordan tegning realiseres i kunst- og håndverksfaget i ungdomsskolen.

\section{Om forfatterne}

Bente Helen Skjelbred er stipendiat ved Høgskulen på Vestlandet Hennes forskingsinteresser omfatter tegning i læreplanen og didaktiske praksiser i faget kunst og håndverk i ungdomskolen.

Institusjonstilknytning: Institutt for Kunstfag, Høgskulen på Vestlandet, Postboks 7030, 5020 Bergen

E-post: $\underline{\text { bhsk@hvl.no }}$

Jorunn Spord Borgen er professor ved Norges Idrettshøyskole og professor II på Høgskulen på Vestlandet. Hennes forskingsinteresser omfatter utdanningsvitenskapelige perspektiver på forståelser av ulike kunnskapsformer i de praktiske og estetiske skolefagene i skole og lærerutdanning, kunst- og kulturformidling for barn og unge, og studier av sammenhenger mellom grunnopplæringen, høyere utdanning, utdanningspolitikk og forskningspolitikk. Institusjonstilknytning: Institutt for lærerutdanning og friluftslivsstudier, Norges idrettshøyskole/ Fakultet for lærerutdanning, kultur og idrett, Høgskulen på Vestlandet, Postboks 7800, 5020 Bergen

E-post: jorunn.spord.borgen@nih.no

\section{Referanser}

Aasen, P., Møller, J., Rye, E., Ottesen, E., Prøitz, T. S. \& Hertzberg, F. (2012).

Kunnskapsløftet som styringsreform-et løft eller et løfte? Forvaltningsnivåenes og institusjonenes rolle i implementeringen av reformen.

Andreassen, S.-E. (2016). Forstår vi læereplanen? (Doktorgradsavhandling). UiT, Norges Artiske Universitet. Hentet fra https://munin.uit.no/bitstream/handle/10037/9671/thesis_entire.pdf?sequence $=3$

Berge, K. L. (2007). Grunnleggende om de grunnleggende ferdighetene. I H. Hølleland (Red.). På vei mot Kunnskapsløftet-Begrunnelser, løsninger og utfordringer, 228-250. 
Bloom, B., Engelhart, M., Furst, E., Hill, W. \& Krathwohl, D. (1956). Taxonomy of educational objectives: The classification of educational goals. Handbook 1: Cognitive domain. New York: David McKay.

Bolin, P. E. \& Blandy, D. (2003). Beyond visual culture: Seven statements of support for material culture studies in art education. Studies in Art Education, 44(3), 246-263.

Borgen, J. S. (1995). Formingsfaget i et oppdragelses-og dannelsesperspektiv. Formingsfagets egenart: en artikkel- og essaysamling. I I. B. Thronshart (Red.), Formingsfagets egenart (s. 44-62). Notodden: Høgskolen i Telemark/Telemarksforskning.

Borgen, J. S. \& Brandt, S. S. (2008). Architectural Education for Young People in Europe: A Comparative Study in Seven European Countries. Norway Country Report.

Borgen, J. S. \& Hjardemaal, F. R. (2017). From general transfer to deep learning as argument for practical aesthetic school subjects? Nordic Journal of Studies in Educational Policy, 3(3), 218-229.

Brænne, K. (2009). Mellom ord og handling: Om verdsetjing i kunst og handverksfaget (Doktorgradsavhandling). Arkitektur-og designhøgskolen i Oslo.

Brænne, K. (2011). Vedlikehald av ein konstruert kontrovers-kunstpedagogikk og handverkstradisjon i kunst-og handverksfaget. Form Akademisk-forskningstidsskrift for design og designdidaktikk, 4(2).

Dagsland, T. P. (2013). Eleven som aktør i dialog med kunst: ungdoms erfaring med kunstundervisningens innhold og metode i faget kunst og håndverk i norsk grunnskole (Doktorgradsavhandling). Åbo Akademi University, Åbo Akademi.

Dagsland, T. P. (2015). Forskningsbasert kunst-og håndverksundervisning. FormAkademiskResearch Journal of Design and Design Education, 8(2).

Dale, E. L., Engelsen, B. U. \& Karseth, B. (2011). Kunnskapsløftets intensjoner, forutsetninger og operasjonaliseringer: En analyse av en læreplanreform. Sluttrapport [The intensions, premises and formulations of the Knowledge Promotion Reform 2006. An analysis of a national curriculum reform. Final report.

Dale, E. L. \& Øzerk, K. (2009). Underveisanalyser av Kunnskapsløftets intensjoner og forutsetninger. Delrapport $n r, 2$.

Doll Jr, W. E. (1979). Doll, William E., Jr.," A Structural View of Curriculum," Theory Into Practice, 18 (December, 1979), 336-348.

Duncum, P. (2002). Clarifying visual culture art education. Art education, 55(3), 6-11.

Eisner, E. W. \& Day, M. D. (2004). Handbook of research and policy in art education Routledge.

Engelsen, B. U. (2003). Ideer som formet vår skole? Lœreplanen som idébœrer-et historisk perspektiv. Oslo: Gyldendal Akademisk.

Engelsen, B. U. (2015). Kan læring planlegges? -Arbeid med læereplaner- hva, hvordan, hvorfor? (7. utg.). Oslo: Gyldendal Akademisk.

Fauskanger, J. \& Mosvold, R. (2014). Innholdsanalysens muligheter i utdanningsforskning. Norsk pedagogisk tidsskrift, 98(02), 127-139.

Frisch, N. S. (2010). To see the visually controlled: Seeing-drawing in formal and informal contexts. A qualitative comparative case study of teaching and learning drawing processes from Vega in Northern Norway.

Frisch, N. S. (2013). Tegningen lever! : nye dialogiske perspektiver på tegneundervisning i grunnskolen. Oslo: Akademika.

Frisch, N. S. (2015). Tegning for morgendagens Norge. FORM Kunst og design i skolen, (5), 4-6.

Garber, E. (2002). Craft education in Finland: definitions, rationales and the future. International Journal of Art \& Design Education, 21(2), 132-145. 
Goodlad, J. I. (1966). The development of a conceptual system for dealing with problems of curriculum and instruction.

Goodlad, J. I. (1977). What goes on in our schools? Educational Researcher, 6(3), 3-6.

Goodlad, J. I. (1979). The scope of the curriculum field. I J. I. Goodlad (Red.), Curriculum inquiry. The study of curriculum practice (s. 17-43). New York: McGraw-Hill Book Company.

Gulliksen, M. S. (2012). Gode Valg-om læreres utvelgelseskompetanse i Kunst og håndverk. FormAkademisk-Research Journal of Design and Design Education, 5(2).

Gulliksen, M. S. \& Johansson, M. (2008). Today and the future-Views on teaching and research within the Nordic sloyd subject. Vasa: NordFo Techne B series.

Gundem. (1990). Lœreplanpraksis og læreplanteori: En introduksjon til læreplanområdet. Oslo: Universitetsforlaget.

Gundem. (2008). Perspektiv på lcereplanen. Bergen: Fagbokforlaget.

Göthlund, A., Illeris, H. \& Thrane, K. (2015). EDGE : 20 essays on contemporary art education. København Multivers Academic.

Hallås, O., Holthe, A., Vindenes, N. \& Styve, E. (2012). De grunnleggende ferdighetene i de praktis-estetiske fagene (s. 111-119): Tapir Trondheim.

Holthe, A., Hallås, O., Styve, E. T. \& Vindenes, N. (2013). Rammefaktorenes betydning for opplæringen i de praktisk-estetiske fagene-en casestudie. Acta Didactica Norge, 7(1), (Art 13, 19 sider).

Hopperstad, M. H. (2005). Alt begynner med en strek-: når barn skaper mening med tegning. Trondheim: Cappelen akademisk.

Horverak, M. O. \& Hidle, K.-M. W. (2017). Mangelfull opplæring i grunnleggende skriveferdigheter. Uniped, 40(02), 155-169.

Hsieh, H.-F. \& Shannon, S. E. (2005). Three approaches to qualitative content analysis. Qualitative health research, 15(9), 1277-1288.

Isnes, A. (2007). Læreplanverket i Kunnskapsløftet II. H. Hølleland. (Red.), På vei mot kunnskapsløftet. Begrunnelser, løsninger og utfordringer (Bind 1, s. 184-199). Oslo: Cappelens Forlag as

Kalleberg, Balto, Cappelen, Nagel, Nymoen, Rønning \& Nagell, H. (2006). Forskningsetiske retningslinjer for samfunnsvitenskap, humaniora, juss og teologi. Oslo: De nasjonale forskningsetiske komiteer, 5-35.

Kjosavik, S. (2003). Fra forming til kunst og håndverk: fagutvikling og skolepolitikk 19741997.

Krathwohl, D. R. (2002). A revision of Bloom's taxonomy: An overview. Theory into practice, 41(4), 212-218.

Kunnskapsdepartementet. (2010). Oppdragsbrev til Utdanningsdirektoratet for budsjettåret 2010.

Kunnskapsdepartementet. (2016). Fag - Fordypning - Forståelse. En fornyelse av Kunnskapsløftet (Meld. St. 28 (2015 - 16)). Oslo: Departementenes servicesenter.

Lindensjö, B. \& Lundgren, U. P. (2000). Utbildningsreformer och politisk styrning HLS förlag.

Milbrandt, M. K., Miraglia, K. M. \& Zimmerman, E. (2018). An Analysis of Current Research in Studies in Art Education and the International Journal of Education Through Art. Studies in Art Education, 59(1), 39-54.

Møller, J., Ottesen, E. \& Hertzberg, F. (2010). Møtet mellom skolens profesjonsforståelse og Kunnskapsløftet som styringsreform. Acta Didactica Norge, 4(1), (Art. 15, 23 sider).

Møller, J., Prøitz, T. S. \& Aasen, P. (2009). Kunnskapsløftet-tung bør å bœre? Underveisanalyse av styringsreformen i skjæringspunktet mellom politikk, administrasjon og profesjon. Oslo NIFU STEP: NIFU STEP. 
Mølstad, C. E. \& Karseth, B. (2016). National curricula in Norway and Finland: The role of learning outcomes. European Educational Research Journal, 15(3), 329-344.

Pedersen, K. (1999). Bo's billedbog: en drengs billedmessige socialisation: Ph. D. thesis Dansk Psykologisk Forlag.

Prøitz \& Borgen. (2010). Rettferdig standpunktvurdering-det (u) muliges kunst? Læereres setting av standpunktkarakter i fem fag i grunnoppleringen. Oslo: NIFU STEP.

Rimstad, Å. (2018). Handlingsrammer og handlingsrom i kunst og handverksfaget. Techne Series-Research in Sloyd Education and Craft Science A, 25(1), 49-58.

Rønning, W., Fiva, T., Henriksen, E., Krogtoft, M., Nilsen, N. O., Skogvold, A. S. \& Solstad, A. G. (2008). Lcreplan, læreverk og tilrettelegging for læring: analyse av lcereplan og et utvalg læereverk i naturfag, norsk og samfunnsfag. Bodø: Nordlandsforskning.

Saarnivaara, M. \& Varto, J. (2005). Art education as a trap. Scandinavian journal of educational research, 49(5), 487-501.

Sivesind, K. \& Westbury, I. (2016). State-based curriculum-making, Part I. Journal of Curriculum Studies, 48(6), 744-756.

Stenhouse, L. (1975). An introduction to curriculum research and development. London.

Svenkerud, S., Klette, K. \& Hertzberg, F. (2012). Opplæring i muntlige ferdigheter. Nordic studies in Education, 32(01), 35-49.

Utdanningsdirektoratet. (2004). Retningslinjer for arbeid med læreplaner for fag. Hentet fra: https://docplayer.me/151086-Retningslinjer-for-arbeid-med-laereplaner-for-fag.html, s. 312.

Utdanningsdirektoratet. (2006). Læreplanverket for Kunnskapsløftet. Oslo.

Utdanningsdirektoratet. (2015). https://www.udir.no/laring-ogtrivsel/lareplanverket/grunnleggende-ferdigheter/skriving/eksempler-pa-god-praksis-iskriving/skriving-prakt-est-fag/er-skriving-viktig/, 1-3.

Utdanningsdirektoratet. (2016). https://www.udir.no/laring-ogtrivsel/vurdering/sluttvurdering/naturfag-rettleiande-nasjonale-kjenneteikn-pamaloppnaing-for-standpunktvurdering-etter-10.-trinn-skolearet/.

Utdanningsdirektoratet. (2017). Rammeverk for grunnleggende ferdigheter. Oslo.

Voogt, J. \& Nieveen, N. (2017). Conceptualizing time lag dilemma in curriculum change An exploration of the literature (Report prepared under the auspices of the OECD Future of Education and Skills 2030 project). Amsterdam: University of Amsterdam.

Yin, R. K. (2009). Case study research: Design and methods (applied social research methods). London Sage.

Yin, R. K. \& Nilsson, B. (2007). Fallstudier: design och genomförande. Malmö: Liber.

Øzerk, K. Z. (2006). Opplcringsteori og læreplanforståelse: en lærebok med vekt på Kunnskapsløftet, Rammeplan for barnehager og aktuelle kunnskaper for pedagoger. Lillehammer: Oplandske Bokforlaget. 